\title{
VECTORIAL ROLE OF SOME DERMANYSSOID MITES (ACARI, Mesostigmata, DeRmanyssoidea)
}

\author{
VALIENTE MORO C.*, CHAUVE C.* \& ZENNER L.*
}

\section{Summary:}

Among transmissible diseases, vectorial diseases represent a major problem for public health. In the group of acarina, while ticks are the most commonly implicated vectors, other arthropods and notably Dermanyssoidea are also involved in the transmission of pathogenic agents. Since the role of this superfamily is at present largely unknown, we have reviewed the vectorial role of these mites in the appearance, survival and propagation of pathogens. Various authors have shown that Dermanyssoidea are implicated in the transmission of both bacteria (Salmonella, Spirocheta, Rickettsia or Pasteurella) and viruses (equine encephalitis viruses, West Nile virus, Fowl pox virus, the virus causing Newcastle disease and tick borne encephalitis viruses or hantaviruses). Finally, some authors have also shown their role in the transmission of some protozoa and filaria. As the vectorial character of such mites has been more clearly demonstrated (Dermanyssus gallinae, Ornithonyssus bacoti and Allodermanyssus sanguineus), it would be interesting to continue studies to better understand the role of this superfamily in the epidemiology of certain zoonoses.

KEY WORDS : Dermanyssoidea, vector, bacteria, virus, parasite.
Résumé : RÔLe VECTEUR des ACARIENS DeRManyssoidea (ACARI, Mesostigmata, Dermanyssoidea)

Parmi les maladies transmissibles, les maladies vectorielles représentent un problème majeur de santé publique. Dans le groupe des acariens, si les tiques sont les vecteurs les plus souvent incriminés, d'autres arthropodes et notamment les acariens Dermanyssoidea sont impliqués dans la transmission d'agents pathogènes. Actuellement, le rôle de cette superfamille est certainement sous-estimé et c'est pourquoi nous avons choisi de réaliser un état des lieux du rôle vecteur de ces acariens dans l'apparition, le maintien et la propagation de pathogènes. Ainsi, différents auteurs ont montré que les Dermanyssoidea sont impliqués dans la transmission de bactéries (salmonelles, spirochètes, rickettsies ou encore pasteurelles), mais également de virus (virus des encéphalites équines, virus de West Nile, virus de la variole aviaire, virus de la maladie de Newcastle, virus des encéphalites à tiques ou des hantavirus). Enfin, certains auteurs ont montré leur rôle dans la transmission de protozoaires et de filaires. Comme le caractère de vecteur a clairement été démontré pour certains acariens, (Dermanyssus gallinae, Ornithonyssus bacoti et Allodermanyssus sanguineus), il serait intéressant de poursuivre les études afin de mieux comprendre le rôle de cette superfamille dans l'épidémiologie de certaines zoonoses.

MOTS CLÉS : Dermanyssoidea, vecteur, bactérie, virus, parasite.

\section{INTRODUCTION}

$\mathrm{D}$ iseases transmitted by arthropods such as arbovirose, malaria, trypanosomiasis or leishmaniasis all play a major role in human health and/ or veterinary medicine (Coulter, 2002; Gubler, 2002a). In addition to their importance for public health, their presence is also an important economic brake to the development of those countries where they are prevalent (Bos \& Mills, 1987; Gubler, 2002b). In order to control them effectively, various strategies have been envisaged: use of drugs, vaccines, anti-vectorial control measures (Carnevale, 1995; Basu, 2002). But to develop such strategies, it is indispensable to have complete knowledge of the epidemiology of these infections and a perfect understanding of the vector-pathogen system,

\footnotetext{
* Unité Mixte de Recherche PEV ENVL/INRA 958, Service de Parasitologie, École Nationale Vétérinaire de Lyon, 1, avenue Bourgelat, BP 83, 69280 Marcy l'Étoile, France.

Correspondence : Lionel Zenner. E-mail: 1.zenner@vet-lyon.fr
}

and especially of the relationship between the host, the vector and the pathogenic agent if we are to predict the risk of transmission of these diseases (Eldridge, 2000).

Acarians are among the vectors often implicated in these pathologies. Ticks are known to be involved in the transmission of babesiosis, in transmission of some encephalitis viruses or arboviruses and also of Lyme disease (Chastel et al, 1988; Belman, 1999; Guiguen \& Degeilh, 2001). Although ticks are important vectors, it has been shown that other acarians can also be implicated in the vectorial transmission of diseases. Among them, the suborder of Mesostigmata and more especially the superfamily of the Dermanyssoidea includes numerous highly diverse species from an ecological point of view and there exist interspecific associations ranging from phoresia to true parasitism (Radovsky, 1985; Radovsky, 1994). Unfortunately, studies dealing with the role of Dermanyssoidea are few and their scope is limited, which could lead to an underestimation of the importance of Dermanyssoidea. 
We have therefore carried out a review of the vectorial role of the acarians belonging to this superfamily and, despite the often fragmented, incomplete and outdated character of some of the data, we want to stress the importance of the appearance, survival and propagation of these pathogenic agents and so demonstrate their not inconsequential role in the transmission of diseases and the importance of further research.

\section{THE DERMANYSSOIDEA SUPERFAMILY}

T This belongs to the order Acarina and to the suborder of Mesostigmata. It includes thirteen families (Table I), some of which containing species considered to be potential vectorial agents. The adoption of a parasitic life style by the members of this superfamily has gone hand in hand with a number of modifications to their life cycle and morphology. Like most of the acarians, we are talking about microscopic species not bigger than one millimetre. We can divide their family into hematophagous ectoparasites, freeliving or facultative ectoparasites or respiratory endoparasites.

On the one hand, the hematophagous ectoparasites, which are of particular interest to us as they can act as vectors, are mostly represented by the Dermanyssidae and Macronyssidae, which are principally parasites of birds and rodents and live in their nests and burrows. The Dermanyssidae are particularly well adapted as they are capable of feeding rapidly

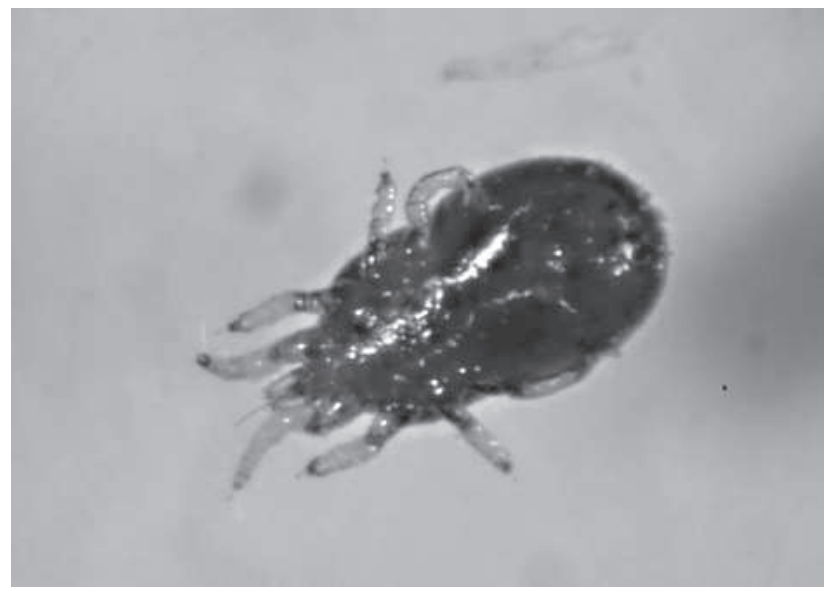

Fig. 1. - Gorged adult Dermanyssus gallinae. The chelicerae are visible.

on the blood of their host using chelicerae in the form of a stylet (Fig. 1) which penetrate the epidermis; they possess the capacity for gorging themselves and are resistant to periods of fasting. The Macronyssidae are also permanent parasites of mammals, birds and reptiles. Other permanent hematophagous ectoparasites include Spinturnicidae and Hystrichonyssidae which parasitize bats and rodents respectively, although their role as vectorial agents is little known.

On the other hand, the free-living or non hematophagous ectoparasites, important in terms of the large number of described species, are represented by the Laelapidae family.

\begin{tabular}{|c|c|c|}
\hline Taxon & Relationships & Potential vector genus \\
\hline Laelapidae & Free-living, facultative or obligatory parasites & $\begin{array}{l}\text { Haemogamasus } \\
\text { Eulaelaps } \\
\text { Hirstionyssus } \\
\text { Laelaps } \\
\text { Clethrionomydes } \\
\text { Hyperlaelaps } \\
\text { Androlaelaps } \\
\text { Haemolaelaps,... }\end{array}$ \\
\hline Macronyssidae & \multirow{3}{*}{$\begin{array}{l}\text { Nest or permanent parasites of mammals, birds, reptiles, bats } \\
\text { or rodents }\end{array}$} & Ornithonyssus \\
\hline Dermanyssidae & & $\begin{array}{l}\text { Dermanyssus } \\
\text { Allodermanyssus }\end{array}$ \\
\hline $\begin{array}{l}\text { Spinturnicidae } \\
\text { Hystrichonyssidae }\end{array}$ & & \\
\hline $\begin{array}{l}\text { Rhinonyssidae } \\
\text { Halarachnidae } \\
\text { Entonyssidae }\end{array}$ & $\begin{array}{l}\text { Parasites in the respiratory passages of mammals, birds and } \\
\text { snakes }\end{array}$ & \\
\hline $\begin{array}{l}\text { Ixodorhynchidae } \\
\text { Omentolaelapidae }\end{array}$ & Parasites of snakes & \\
\hline Dasyponyssidae & Parasites of armadillos & \\
\hline Manitherionnyssidae & One specie parasite of pangolins & \\
\hline Varroidae & Nest parasites of honeybees & \\
\hline
\end{tabular}

Table I. - Classification and feeding relationships of the Dermanyssoidea (modified from Radovsky, 1985). 
Finally, there are the endoparasites of the respiratory apparatus represented by the Halarachnidae, Rhinonyssidae and Entonyssidae families which are parasites of mammals, birds and snakes respectively. The Ixodorhynchidae and Omentolaelapidae families are snake parasites, the Dasyponyssidae and Manitherionyssidae families are respectively parasites of the Armadillos and Pangolins and the Varroidae family are to be found in bee hives.

Our interest will be primarily on the families that are the most often incriminated as potential vectors for disease, i.e. Dermanyssidae, Macronyssidae and Laelapidae.

\section{PATHOGENIC AGENTS CARRIED BY DERMANYSSOIDEA}

The Dermanyssoidea have been implicated in the transmission of viruses (Table II). Animal viruses like fowl-pox and Newcastle disease have been shown in varying degrees to be linked to acarians (Shirinov et al., 1972; Arzey, 1990). The hantavirus is an example of one of the viruses causing serious zoonoses which has been isolated from these acarians (Wu et al., 1998; Zhuge et al., 1998; Iakimenko et al., 2000; Zhang et al., 2001; Zhang et al., 2002). Fur-

\begin{tabular}{|c|c|c|c|c|}
\hline Virus & Mite & Host & Characteristics & Reference \\
\hline \multirow{5}{*}{$\begin{array}{c}\text { Hantavirus } \\
\text { Hemorrhagic } \\
\text { fever }\end{array}$} & H. glasgowi & Wild rodents' nests & Biological vector & Dong, 1991 \\
\hline & O. bacoti & Rat & Vector and reservoir & Zhuge et al., 1998 \\
\hline & $\begin{array}{l}\text { E. shanghaiensis, } \\
\text { O. bacoti }\end{array}$ & Mice & Bite transmission & Meng et al., 1990 \\
\hline & H. ambulans & Siberian lemming & Virus isolation & Iakimenko et al., 2000 \\
\hline & Gamasid mite & Wild rodents' nests & $\begin{array}{c}\text { Virus detection } \\
\text { Vector and reservoir }\end{array}$ & Zhang et al., 2001 \\
\hline \multirow{2}{*}{$\begin{array}{c}\text { Saint-Louis } \\
\text { encephalitis } \\
\text { virus (Flavirus) }\end{array}$} & $\begin{array}{c}\text { D. gallinae } \\
\text { O. bursa, O. sylviarum }\end{array}$ & Mice & No bite transmission & Chamberlain et al., 1957 \\
\hline & B. sylviarum, D. americanus & Birds' nests & Neither vector nor reservoir & Reeves et al., 1955 \\
\hline $\begin{array}{l}\text { Fowl poxvirus } \\
\text { Smallpox }\end{array}$ & D. gallinae & $\begin{array}{l}\text { Infected birds } \\
\text { Poultry farms }\end{array}$ & $\begin{array}{c}\text { Transovarian transmission } \\
\text { Bite transmission }\end{array}$ & Shirinov et al., 1972 \\
\hline $\begin{array}{c}\text { Avian } \\
\text { paramyxovirus } \\
\text { type } 1 \\
\text { Newcastle disease }\end{array}$ & O. sylviarum, D. gallinae & & $\begin{array}{l}\text { Suspected role in the spread } \\
\text { of the disease }\end{array}$ & Arsey, 1990 \\
\hline $\begin{array}{l}\text { West Nile virus } \\
\text { (Flavirus) }\end{array}$ & Hematophagous gamasid mites & Birds' nests & Virus isolation & Iakimenko et al., 1991 \\
\hline \multirow{13}{*}{$\begin{array}{c}\text { Tick-borne } \\
\text { encephalitis } \\
\text { virus (Flavirus) }\end{array}$} & O. bacoti, D. gallinae & Mice & No viral replication in mites & Durden et al., 1993 \\
\hline & L. agilis & Wild rodents & Rodents carrying mites found seropositive & Kocianova et al., 1993 \\
\hline & $\begin{array}{c}\text { D. gallinae, D. hirundinis } \\
\text { A. casalis }\end{array}$ & Birds & No viral detection & Korenberg et al., 1984 \\
\hline & $\begin{array}{l}\text { H. mandschuicus, } \\
\text { L. cletbrionomydis, } \\
\text { E. stabularis, A. glasgowi }\end{array}$ & & $\begin{array}{c}\text { Conservation of the virus after } \\
\text { experimental infection } \\
\text { Transmission to host }\end{array}$ & Naumov et al., 1984 \\
\hline & H. isabellinus, H. ambulans & Wild rodents' nests & Virus isolation & Shaiman et al., 1976 \\
\hline & D. gallinae & Mice & No bite transmission & Wegner, 1976 \\
\hline & $\begin{array}{c}\text { E. stabularis, H. glasgowi } \\
\text { H. nidi, D. gallinae } \\
\text { O. bacoti }\end{array}$ & Mice, fowls & $\begin{array}{l}\text { D. gallinae and } O \text {. bacoti infected } \\
\text { No viral conservation } \\
\text { No bite transmission }\end{array}$ & Zemskaya et al., 1962 \\
\hline & O. bacoti & Mice & Viral immune response induction & Zemskaya et al., 1974 \\
\hline & O. bacoti & Mice & Transovarian transmission & Zemskaya et al., 1974 \\
\hline & H. ambulans, H. isabellinus & Lemmings' nests & Virus isolation & Kornilova et al., 1975 \\
\hline & $\begin{array}{c}\text { L. clethrionomydis } \\
\text { H. serdjukovae }\end{array}$ & Rodents & Possible role of mites in virus circulation & Chernykh et al., 1974 \\
\hline & $\begin{array}{c}\text { H. nidi, H. birsutus } \\
\text { H. talpae, A. fabrenbolzi }\end{array}$ & Moles' nests & Virus isolation & Kocianova et al., 1988 \\
\hline & H. nidi, E. stabularis & $\begin{array}{l}\text { Wild rodents' nests, } \\
\text { wild rodents }\end{array}$ & Virus isolation & Gil'Manova et al., 1964 \\
\hline
\end{tabular}

Table II. - Viruses likely to be transmitted by dermanyssoid mites (Equine encephalitis caused by Togavirus are shown in Table V). ( $A$. casalis $=$ Androlaelaps casalis, $A$. fabrenbolzi $=$ Androlaelaps fahrenholzi, A. glasgowi $=$ Androlaelaps glasgowi, B. sylviarum $=$ Bdellonyssus sylviarum, D. americanus = Dermanyssus americanus, D. hirundinis = Dermanyssus hirundinis, E. shanghaiensis = Eulaelaps shanghaiensis, E. stabularis $=$ Eulaelaps stabularis, $H$. ambulans $=$ Haemogamasus ambulans, $H$. glasgowi $=$ haemolaelaps glasgowi, A. hirsutus $=H a e-$ mogamasus birsutus, H. isabellinus = Hirstionyssus isabellinus, H. nidi = Haemogamasus nidi, H. mandschuicus = Haemolaelaps mandschuicus, H. serdjukovae = Haemogamasus serdjukovae, H. talpae = Hirstionyssus talpae, L. agilis = Laelaps agilis, L. clethrionomydis $=$ Laelaps clethrionomydis, O. bacoti = Ornithonyssus bacoti, O. bursa = Ornithonyssus bursa, O. sylviarum = Ornithonyssus sylviarum). 
thermore, for some species, transtadial and transovarian transmission has been demonstrated, as has transmission to rodents through bites (Meng et al, 1990; Dong, 1991). Similarly, the virus of Saint-Louis encephalitis has been isolated from these acarians but without proof of them playing a vectorial or reservoir role (Reeves et al., 1955; Chamberlain et al., 1957). Other viruses, such as the West Nile virus, the tickborne encephalitis virus and the togaviruses have also been isolated from these arthropods: in some cases, they have a potential vectorial role (Zemskaya \& Pchelkina, 1962; Gil'Manova et al., 1964; Chernykh et al., 1974; Zemskaya \& Pchelkina, 1974a; Zemskaya \& Pchelkina, 1974b; Kornilova et al., 1975; Shaiman \& Tarasevich, 1976; Wegner, 1976; Naumov \& Gutova, 1984; Kocianova \& Kozuch, 1988; Iakimenko et al., 1991; Durden \& Turell, 1993; Kocianova et al., 1993; Korenberg et al., 1993). These togaviruses, causing Eastern, Western and Venezuelan equine encephalitis will be considered in more details further on.

Several authors have underlined the role of acarians in the transmission of bacteria (Table III). Among the species responsible for zoonoses, Francisella tularensis, an agent for tularaemia, has been identified as being transmitted mechanically by various species of Dermanyssoidea like Tabanidae, Simuliidae or Ixo- didae... (Timofeeva, 1964; Petrov, 1971; Zuevskii, 1976; Algazin \& Bogdanov, 1978; Lysy et al., 1979). Similarly, the Salmonella, Yersinia, Listeria, Pasteurella and Bacillus genera have also been isolated from these acarians but again without proof of their vectorial role (Sturman, 1965; Poyarkov \& Avchinnikov, 1966; Wilson \& MacDonald, 1967; Grebenyuk et al., 1972; Petrov, 1975; Sotnikova et al., 1977; Romasheva \& Uzdenov, 1979; Zeman et al., 1982). Some rickettsia bacteria have also been isolated and this case will be analysed in more details later in this paper. Dermanyssus gallinae has been shown to be an occasional vector for spirochetes without being a natural reservoir and Borrelia bugdorferi, responsible for Lyme disease, is suspected of having been transmitted by Ornithonyssus bacoti by some authors (Ciolca et al., 1968; Reshetnikov, 1967; Stajkovic et al., 1993; Lopatina et al., 1999). Finally, $D$. gallinae has been cited as a potential vector and reservoir of Erysipelothrix rhusiopathiae, the agent causing swine erysipelas (Chirico et al., 2003).

With regard to parasites (Table IV), some authors have demonstrated the role played by Ornithonyssus bacoti as a mechanical vector in the transmission of Trypanosoma cruzi in an experimental model (Cortez-Jimenez, 1994) and have succeeded in transmitting other protozoa such as Hepatozoon sp. and Elleipsisoma thomsoni under

\begin{tabular}{|c|c|c|c|c|}
\hline Bacteria & Mite & Host & Characteristics & References \\
\hline \multirow{4}{*}{$\begin{array}{c}\text { Francisella } \\
\text { tularensis } \\
\text { (tularemia) }\end{array}$} & $\begin{array}{l}\text { H. ambulans } \\
\text { H. isabellinus }\end{array}$ & Wild rodents' nests & Bacterial isolation & Algazin et al., 1978 \\
\hline & H. nidi, L. hilaris & Wild rodents & Bacterial isolation & Lysy et al., 1979 \\
\hline & O. bacoti & Mice & $\begin{array}{l}\text { Transmission by ingestion or crushing } \\
\text { on skin of mites }\end{array}$ & Petrov, 1971 \\
\hline & H. musculi & Wild rodent & Transmission by ingestion of mites & Timofeeva et al., 1964 \\
\hline $\begin{array}{l}\text { Salmonella } \\
\text { gallinarum }\end{array}$ & D. gallinae & Fowls & Bacterial isolation & Zeman et al., 1982 \\
\hline $\begin{array}{c}\text { Salmonella } \\
\text { typhimurium }\end{array}$ & $\begin{array}{c}\text { L. hilaris, L. pavlovskyi, } \\
\text { H. arvalis, H. hirsutus } \\
\text { H. musculi, H. isabellinus }\end{array}$ & Wild rodents & Bacterial isolation & Poyarkov et al., 1966 \\
\hline $\begin{array}{l}\text { Erysopelothrix } \\
\text { rhusiopathiae }\end{array}$ & D. gallinae & Fowls & $\begin{array}{c}\text { Bacterial isolation } \\
\text { Vector and reservoir }\end{array}$ & Chirico et al., 2003 \\
\hline \multirow[t]{2}{*}{ Spirochaetosis } & D. gallinae & Fowls & $\begin{array}{l}\text { Occasionnal vector } \\
\text { Mite fecal excretion }\end{array}$ & Ciolca et al., 1968 \\
\hline & D. gallinae & Chickens & Transmission to chickens & Reshetnikov, 1967 \\
\hline $\begin{array}{c}\text { Borrelia } \\
\text { bugdorferi } \\
\text { (lyme disease) }\end{array}$ & $\begin{array}{c}\text { O. bacoti } \\
\text { Haemogamasus sp. }\end{array}$ & $\begin{array}{c}\text { Mice } \\
\text { Wild rodents }\end{array}$ & $\begin{array}{l}\text { Bite transmission } \\
\text { Bacteria isolated from rodents }\end{array}$ & $\begin{array}{l}\text { Lopatina et al., } 1999 \\
\text { Stajkovic et al., } 1993\end{array}$ \\
\hline $\begin{array}{c}\text { Pasteurella } \\
\text { multocida }\end{array}$ & D. gallinae & Birds & Vector, no direct transmission & Petrov, 1975 \\
\hline $\begin{array}{c}\text { Bacillus } \\
\text { thuringiensis }\end{array}$ & D. gallinae & Birds & Bacterial isolation & Romasheva et al., 1979 \\
\hline $\begin{array}{c}\text { Yersinia } \\
\text { rodentium }\end{array}$ & D. birundinis & Birds nest & Bacterial isolation & Sotnikova et al., 1977 \\
\hline $\begin{array}{c}\text { Listeria } \\
\text { monocytogenes }\end{array}$ & D. gallinae & Wild and domestic animals & Bacterial isolation & Grebenyuk et al., 1972 \\
\hline
\end{tabular}

Table III. - Bacteria likely to be transmitted by dermanyssoid mites (Rickettsia and Coxiella are shown in Table VI). (D. hirundinus $=$ Dermanyssus hirundinis, H. ambulans = Haemogamasus ambulans, H. arvalis = Hyperlaelaps arvalis, H. isabellinus = Hirstionyssus isabellinus, H. hirsutus = Haemogamasus hirsutus, H. musculi = Hirstionyssus musculi, H. nidi = Haemogamasus nidi, L. hilaris = Laelaps hilaris, L. pavlovskyi $=$ Laelaps pavlovskyi, O. bacoti = Ornithonyssus bacoti). 
experimental conditions (Redington \& Jachowski, 1971; Frank, 1977; Mohamed et al., 1987). Filaria of the Litomosoides genus have also been shown to be capable of developing inside certain species of Dermanyssoidea (Renz \& Wenk, 1981; Diagne et al., 1989).

\section{EQUINE ENCEPHALITIS CAUSED BY TOGAVIRUSES}

The American forms of this disease, Eastern and Western equine encephalitis (EEE and WEE), as _ well as the Venezuelan form (VEE) are responsible for serious nervous disorders in both the horse and man. The nature of the disorder may be encephalic or myelitic. Transmission occurs almost exclusively via the mosquito and the perenniality of the disease is ensured by the existence of the reservoir hosts (birds and rodents). The Dermanyssoidea have been suspected on a few occasions of being the vectors of these encephalitis (Table V).

In order to evaluate their vector role, research teams have carried out experiments using the following method: they let the acarians feed on previously infected hosts and then tested them for the presence of the pathogenic agent. If the acarians were infected, they were then allowed to feed on non-infected hosts so that the possible viral transmission could be studied. These experiments were designed to include a variable time delay between the moment when the arthropod

\begin{tabular}{|c|c|c|c|c|}
\hline Parasite & Mite & Host & Characteristics & References \\
\hline \multicolumn{5}{|l|}{ Protozoa } \\
\hline $\begin{array}{c}\text { Hepatozoon } \\
\text { sylvatici }\end{array}$ & L. agilis & Wild rodents & Experimental transmission & Frank et al., 1977 \\
\hline $\begin{array}{c}\text { Hepatozoon } \\
\text { griseisciuri }\end{array}$ & H. reidi & Squirrels & Biological vector & Redington et al., 1971 \\
\hline $\begin{array}{c}\text { Elleipsisoma } \\
\text { thomsoni }\end{array}$ & $\begin{array}{l}\text { H. birsutus, H. nidi, } \\
\text { E. stabularis }\end{array}$ & Moles' nests & Biological vector & Mohamed et al., 1987 \\
\hline $\begin{array}{c}\text { Trypanosoma } \\
\text { cruzi }\end{array}$ & O. bacoti & Mice & Mechanical vector & Cortez-Jimenez et al., 1994 \\
\hline \multicolumn{5}{|l|}{ Nematodes } \\
\hline $\begin{array}{c}\text { Litomosoides } \\
\text { galizai }\end{array}$ & B. bacoti & & Biological vector & Diagne et al., 1989 \\
\hline $\begin{array}{l}\text { Litomosoides } \\
\text { sigmondontis }\end{array}$ & B. bacoti & & Biological vector & Diagne et al., 1989 \\
\hline $\begin{array}{c}\text { Litomosoides } \\
\text { carinii }\end{array}$ & O. bacoti & & Experimental vector & Renz et al., 1981 \\
\hline
\end{tabular}

Table IV. - Parasites likely to be transmitted by dermanyssoid mites. (B. bacoti = Bdellonyssus bacoti, E. stabularis = Eulaelaps stabularis, H. hirsutus = Haemogamasus hirsutus, $H$. nidi $=$ Haemogamasus nidi, H. reidi $=$ Haemogamasus reidi, L. agilis = Laelaps agilis, O. bacoti $=$ Ornithonyssus bacoti).

\begin{tabular}{|c|c|c|c|c|}
\hline Virus & Mite & Host & Characteristics & References \\
\hline \multirow{3}{*}{$\begin{array}{l}\text { Eastern equine } \\
\text { encephalitis } \\
\text { virus (EEE) }\end{array}$} & H. liponyssoides, O. bacoti & Mice & $\begin{array}{l}\text { Virus persistence in mites: } 11 \text { to } 46 \text { days } \\
\text { No bite transmission, no viral replication }\end{array}$ & Clark et al., 1966 \\
\hline & D. gallinae & Chickens & $\begin{array}{c}\text { Virus persistence in mites: } 30 \text { days } \\
\text { Bite transmission, no viral replication } \\
\text { No transovarian transmission }\end{array}$ & Durden et al., 1993 \\
\hline & D. gallinae & Chickens & $\begin{array}{l}\text { Virus persistence in mites: } 15 \text { days } \\
\text { No transovarian transmission }\end{array}$ & Chamberlain et al., 1955 \\
\hline \multirow{4}{*}{$\begin{array}{l}\text { Western equine } \\
\text { encephalitis } \\
\text { virus (WEE) }\end{array}$} & $\begin{array}{l}\text { B. sylvarium, D. gallinae, } \\
\text { D. americanus }\end{array}$ & Wild birds nests & Viral isolation & Reeves et al., 1955 \\
\hline & D. americanus & $\begin{array}{c}\text { Sparrow } \\
\text { (Passer domesticus) }\end{array}$ & $\begin{array}{c}\text { Viral isolation } \\
\text { No transvarian transmission }\end{array}$ & Cockburn et al., 1957 \\
\hline & D. gallinae & Chickens & No infection of mites & Sulkin et al., 1955 \\
\hline & D. gallinae & Chickens & & Chamberlain et al., 1955 \\
\hline $\begin{array}{l}\text { Venezuelan equine } \\
\text { encephalitis } \\
\text { virus (VEE) }\end{array}$ & D. gallinae, L. kochi & Mice & $\begin{array}{l}\text { Mechanical vector } \\
\text { No viral replication, no transovarian } \\
\text { transmission }\end{array}$ & Durden et al., 1992 \\
\hline
\end{tabular}

Table V. - Equine encephalitis virus transmitted by dermanyssoid mites. (B. sylviarum $=$ Bdellonyssus sylviarum, D. americanus $=$ Dermanyssus americanus, H. liponyssoides = Haemogamasus liponyssoides, L. kochi $=$ Laelaps kochi, O. bacoti = Ornithonyssus bacoti). 


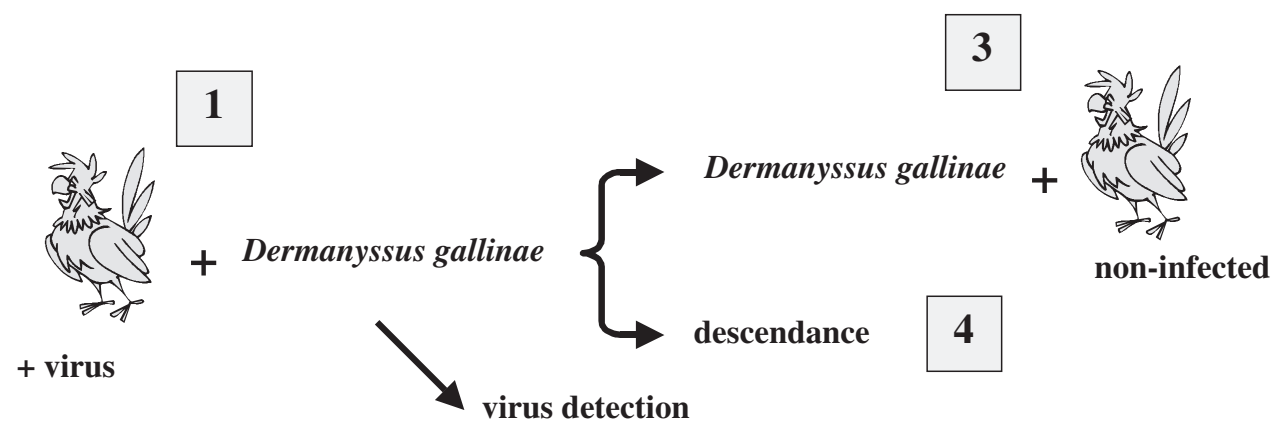

2

Fig. 2. - General methods to asses the vector role of dermanyssoid mites in equine encephalitis caused by togavirus. Acarians feed on a previously infected host (1) and are then tested for the presence of the virus (2). They are then allowed to feed on a non-infected host so that the possible viral transmission could be studied (3). Offspring were also analysed (4).

acquired the virus and the moment when it took a blood meal from a new host when transmission of the virus became possible. The offspring of acarians who had fed from an infected host was then systematically analysed to assess possible transovarian transmission (Fig. 2).

For the virus causing Eastern equine encephalitis (EEE), Clark et al. (1966) demonstrated that both Haemogamasus liponyssoides and Ornithonyssus bacoti could ingest enormous quantities of the virus when feeding on the blood of infected mice. Depending on the temperature, these viruses persisted for up to 46 days in the acarian but no viral replication was observed in the vector and there was no observed transmission of the virus through the bites. However, Chamberlain \& Sikes (1955) and Durden et al. (1993) showed that Dermanyssus gallinae who gorged on infected chicks remained carriers for at least a month without viral replication, and without transmitting the virus to their offspring, although they were able to transmit the virus to other chicks through their bites when taking a blood meal. Extrinsic incubation was a maximum of 26 days in both cases. The attempt to isolate the virus from acarian excrement was unsuccessful.

In the case of the virus causing Western equine encephalitis (WEE), nine viral strains were isolated from Bdellonyssus sylviarum and Dermanyssus americanus between 1946 and 1949, collected from wild birds' nests in California (Reeves et al., 1955). In another similar case of WEE in a Colorado man, it was sparrow on the patient's farm who was found carrying a D. americanus with the virus (Cockburn et al., 1957). All the laboratory experiments to study the vectorial role of Dermanyssoidea were performed some time ago and their results were varied. Reeves et al. (1955) and Sulkin et al. (1955) did not succeed in either transmitting the infection to D. gallinae and B. sylviarum from infected chickens or in transmitting the virus to healthy birds. However, Cockburn et al. (1957) obtained an infestation from D. gallinae who had fed on infected chickens, but were not able to demonstrate either transmission to healthy birds or transovarian transmission in the acarian. Finally, Chamberlain and Sikes (1955) experimentally infected healthy chickens using D. gallinae which had themselves become contaminated during a blood meal on infected birds. In this final case, the extrinsic incubation period was 13 days. With regard to the Venezuelan equine encephalitis virus (VEE), Durden et al. (1992) showed, in experiments in the mouse, that D. gallinae was a mechanical vector in transmission of the virus. However, Laelaps $k o c h i$ neither became infected nor was shown to infect healthy mice. No viral replication or transovarian transmission could be demonstrated.

So, for the forms of equine encephalitis caused by the togaviruses, the role of $D$. gallinae as a mechanical vector for the virus has been clearly shown even though its precise role in the epidemiology of this pathology still remains to be defined. However, for the other Dermanyssoïdea, no conclusive data are available.

\section{RICKETTSIOSES AND Q FEVER}

R ickettsioses are responsible for an important mortality rate in the world; the source is endemic and sometimes causes epidemics. Their vector for transmission are arthropods (fleas, lice, ticks...) and often have a wild animal as their reservoir host. The coevolution between the rickettsia and the arthropods are responsible for many of the relational characteristics of the host/pathogen pair including efficient replication of the pathogen, maintenance of the infection in the long term and transtadial and transovarian transmission (Azad, 1988).

Coxiella burnetii, the bacteria responsible for $\mathrm{Q}$ fever, was for a long time considered to be part of the Ric- 
kettsia ( $R$. burnetii) genus. It has a world-wide geographical distribution with the exception of New Zealand and the animal reservoir includes numerous species of both wild and domesticated animals (cattle, pets, rodents, poultry...). It is mainly contracted by inhalation of dust in which the $C$. burnetii can remain virulent for very long periods and transmission by infected ticks is also possible though exceptional.

The acarians of the Dermanyssoidea superfamily have been implicated in the vectorial transmission of these bacterial agents for several reasons (Table VI).

It was Huebner et al. (1946) who first thought that Rickettsia akari was vectored by Liponyssoides sanguineus and acted as a reservoir for this infectious agent. However, Yunker et al. (1975) were unable to isolate other species of the Rickettsia genus from rodent hosted acarian parasites such as Laelaps dearmasi, Ornithonyssus bacoti, Eubrachylaelaps jamesoni and Haemogamasus glasgowi although several authors, quoted in their article, had demonstrated the winter-long survival of rickettsia in Laelapidae, as well as transtadial, transovarian and host-to-host transmission of certain species of Dermanyssoidea. Rehacek et al. (1975) experimentally infected Dermanyssoidea with rickettsia and showed that these acarians participate in the circulation of the bacteria and their transfer among small mammals but could draw no conclusions as to their possible role as a reservoir and/or biological or mechanical vector. Conversely, Sonenshine et al. (1978) put forward the hypothesis that Haemogamasus reidi and Androlaelaps fahrenbolzi were both involved in the vectorial transmission of $R$. prowazekii after observing a natural infection among squirrels but analysis of the serum from animals inoculated with a suspension of these acarians showed no infection.
Coxiella burnetii has been isolated from nine species of Dermanyssoidea including Allodermanyssus sanguineus and Hirstionyssus criceti, both associated with birds and rodents, taken from places where Q fever was present (Zemskaya \& Pchelkina, 1968). Kocianova et al. (1989, 1993) experimentally infected Haemogamasus nidi, H. hirsutus, Eulaelaps stabularis, Androlaelaps fabrenholzi and $A$. casalis with this bacteria and showed that it was later present in the mite faeces even if it was not possible to isolate the bacteria from acarians taken from mole nests. Finally, Zemskaya \& Pchelkina (1967) demonstrated experimentally that Dermanyssus gallinae, Ornithonyssus bacoti and Allodermanyssus sanguineus were all capable of becoming contaminated when feeding on the blood of infected animals and that the bacteria could survive at least six months in live acarians, and up to one year in dead acarians. Under experimental conditions $D$. gallinae transmitted $C$. burnetii from a guinea pig to birds and vice versa during their blood meals. O. bacoti was also able to act as a transmission agent between guinea pigs and birds, between birds, and between birds and guinea pigs: transovarian transmission was also noted. Similarly, A. sanguineus was able to transmit bacteria between birds and rodents (mice and guinea pigs).

So for bacteria of the Rickettsia genus, only Allodermanyssus sanguineus has actually been acknowledged as a principal vector of $R$. akari. For the other rickettsia, several isolations have been observed from acarians of the Dermanyssoidea superfamily but their role as true vectors still needs to be studied. Lastly, it has been shown that some species of Dermanyssoidea (O. bacoti, $D$. gallinae and A. sanguineus) do act as vectors for $C$. burnetii under experimental conditions and the

\begin{tabular}{|c|c|c|c|c|}
\hline Bacteria & Mite & Host & Characteristics & Reference \\
\hline Rickettsia sp. & $\begin{array}{l}\text { L. dearmasi, O. bacoti, } \\
\text { E. jamesoni, H. glasgowi }\end{array}$ & Rodents & $\begin{array}{l}\text { No bacterial isolation } \\
\text { Transovarian and trans-stadial transmission } \\
\text { Transmission from host to host }\end{array}$ & Yunker et al., 1975 \\
\hline Rickettsia akari & A. sanguineus & & $\begin{array}{c}\text { Natural vector } \\
\text { Bacterial isolation } \\
\end{array}$ & Huebner et al., 1946 \\
\hline $\begin{array}{l}\text { Rickettsia sp. } \\
\text { (Spotted } \\
\text { fever group) }\end{array}$ & Dermanyssoidea & Moles' nests & $\begin{array}{l}\text { Transfer among small mammals } \\
\text { No definitive conclusion }\end{array}$ & Rehacek et al., 1975 \\
\hline $\begin{array}{l}\text { Rickettsia } \\
\text { prowazeki }\end{array}$ & H. reidi, A. fabrenbolzi & Squirrels & No experimental infection & Sonenshine et al., 1978 \\
\hline \multirow{3}{*}{ Coxiella burnetii } & A. sanguineus, H. criceti & Birds, rodents & Bacterial isolation & Zemskaya et al., 1968 \\
\hline & $\begin{array}{c}\text { H. nidi, H. hirsutus } \\
\text { E. stabularis, A. casali, } \\
\text { A. fabrenbolzi }\end{array}$ & Moles & Bacterial isolation from feces of mites & $\begin{array}{l}\text { Kocianova et al., } 1988, \\
\quad \text { Kocianova, } 1989\end{array}$ \\
\hline & $\begin{array}{l}\text { D. gallinae, O. bacoti } \\
\text { A. sanguineus }\end{array}$ & Birds, rodents & $\begin{array}{l}\text { Bacterial survival: } 6 \text { months to } 1 \text { year } \\
\text { Experimental transmission from host to host }\end{array}$ & Zemskaya et al., 1967 \\
\hline
\end{tabular}

Table VI. - Rickettsia and Coxiella transmitted by dermanyssoid mites. (A. casalis $=$ Androlaelaps casalis, A. fahrenholzi $=$ Androlaelaps fabrenholzi, A. sanguineus $=$ Allodermanyssus sanguineus, E. jamesoni $=$ Eubrachylaelaps jamesoni, E. stabularis = Eulaelaps stabularis, H. criceti $=$ Haemogamasus criceti, H. glasgowi $=$ Haemolaelaps glasgowi, H. hirsutus = Haemogamasus hirsutus, H. nidi $=$ Haemogamasus nidi, $H$. reidi $=$ Haemogamasus reid $i, L$. dearmas $i=$ Laelaps dearmasi, $O$. bacoti $=$ Ornithonyssus bacoti $)$. 
lengthy survival of the bacteria in the acarian has been observed. Vertical transmission of $O$. bacoti has also been demonstrated (Zemskaya \& Pchelkina, 1967). As with the viruses causing equine encephalitis, their epidemiological role in the field still needs to be defined.

\section{DERMANYSSIDAE AND MACRONYSSIDAE: THE ONLY REAL BIOLOGICAL VECTOR?}

he Dermanyssoidea represent a vast group of ubiquitous acarians, many of which live in a close relationship with rodents and birds, in their nests, burrows or on the surface of their hosts. Some species are hematophagous parasites while others are facultative parasites (Radovsky, 1985). The range of their hosts is very large and they can easily parasite other species including farmed animals and man should they come into contact with them. So there exist important zoonotic reservoirs (rodents, birds), acarian parasites (Dermanyssoidea) and possible hosts (man, domestic animals, pets). Furthermore, the ability of these acarians to survive periods of prolonged fasting, their ubiquitous character and their resistance make them interesting vectors for the dissemination and conservation of pathogens. This also makes them highly suitable agents for maintaining an area of endemic disease.

Among the acarians, the hematophagous parasites are the best adapted to this vectorial role. In effect, they possess mouthparts and a biological cycle very similar to that observed in ticks. Bibliographical data confirm this idea since the only Dermanyssoidea for which the vectorial character has been formally demonstrated are Dermanyssus gallinae, Ornithonyssus bacoti and Allodermanyssus sanguineus, all three hematophagous parasites of the Dermanyssidae (Dermanyssus gallinae, Allodermanyssus sanguineus) and Macronyssidae (Ornithonyssus bacoti) families. This does not preclude that other, less studied species may also be involved but there are insufficient data to support or refute this. Nevertheless, it is probable that we are talking here about purely mechanical vectors whereas the vectorial role of $D$. gallinae and $O$. bacoti is much more complex. This has been shown for these two species in that transtadial and transovarian transmission of pathogens such as the hantavirus, the tick-borne encephalitis virus, the avian pox virus, rickettsia and coxiella have all been observed.

\section{CONCLUSION}

ome of these mites are clearly vectors for pathoS gens, but a great deal of study is still required if we are to fully understand the vectorial role of these acarians. From a biological point of view, we need to precisely define the various types of vector in relation to the pathogenic agents. To do this, it will be necessary to develop models based on either Dermanyssus gallinae or Ornithonyssus bacoti and to repeat the previous studies using modern techniques of molecular biology to detect the pathogens (Cortinas et al., 2002) and study the life-cycles in vitro of these acarians (Bruneau et al., 2001). The role of these vectors in the epidemiology of these zoonoses in relation to the principal vector (notably ticks) and to the continued survival and dissemination of these pathogens still remains to be defined. The development of further research appears vital in view of the importance of these diseases to public health.

\section{REFERENCES}

Algazin I.P. \& Bogdanov I.I. The role of Lemmings in natural foci of tularaemia in the Trans-polar Region. Zurnal mikrobiologii, èpidemiologii i immunobiologii, 1978, 2, 93-97.

Arzey G. Mechanism of spread of Newcastle disease. Technical Bulletin - New South Wales, Agriculture and Fisheries, 1990, 42, 12.

AZAD A.F. Relationship to vector biology and epidemiology of louse and flea-borne rickettsioses. In: Biology of Rickettsial Diseases, Walker D.H. (ed), CRC Press, Boca Raton, Florida, 1988, 52-62.

BASU S. Initiating malaria control programs in the third world: directives for short and long-term solutions. Journal of Health \& Social Policy, 2002, 15, 59-75.

Belman A.L. Tick borne diseases. Seminars in Pediatric Neurology, 1999, 6, 249-266.

Bos R. \& Mills A. Financial and economic aspects of environmental management for vector control. Parasitology Today, 1987, 3, 160-163.

Bruneau A., Dernburg A., Chauve C. \& Zenner L. First in vitro cycle of the chicken mite, Dermanyssus gallinae, utilizing an artificial feeding device. Parasitology, 2001, 123, 583589.

Carnevale P. Vector control, perspectives and realities. Médecine Tropicale, 1995, 55, 56-65.

Chamberlain R.W. \& SiKes R.K. Laboratory investigations of the role of bird mites in the transmission of Eastern and Western equine encephalitis. The American Journal of Tropical Medicine and Hygiene, 1955, 4, 106-118.

Chamberlain R.W., Sikes R.K. \& Sudia W.D. Attempted laboratory infection of bird mites with the virus of Saint-Louis encephalitis. The American Journal of Tropical Medicine and Hygiene, 1957, 6, 1047-1053.

Chastel C., Le lay G., Legrand-Quillien M.C. \& Le Goff F. Uneven distribution of arboviruses transmitted by ticks in sea bird colonies north and south of France. Comptes rendus de l'académie des sciences III, 1988, 307, 479-484.

Chernykh P.A., Chipanina V.M. \& Feoktistov A.K. Gamasid mites of rodents in foci of tick-borne encephalitis of the Priamure. Parazitologiia, 1974, 8, 426-431. 
Chirico J., Eriksson H., Fossum O. \& Jansson D. The poultry red mite, Dermanyssus gallinae, a potential vector of Erysipelothrix rhusiopathiae causing erysipelas in hens. Medical and Veterinary Entomology, 2003, 17, 232-234.

Ciolca A.L. Tanase I. \& May I. Role of the poultry red mite, Dermanyssus gallinae, in the transmission of spirochaetosis. Archivum Veterinarium Polonicum, 1968, 5, 207215.

Clark G.M., LutZ A.E. \& Fadness L. Observations on the ability of Heamogamasus liponyssoides Ewing and Ornithonyssus bacoti Hirst (Acarina, Gamasina) to retain eastern equine encephalitis virus: preliminary report. The American Journal of Tropical Medicine and Hygiene, 1966, 15, 107-112.

Cockburn T.A., SoOter C.A. \& Langmuir A.D. Ecology of Western equine and Saint-Louis encephalitis viruses. A summary of field investigations in weld county, Colorado 1949-53. American Journal of Hygiene, 1957, 65, 130-146.

CoRTEZ-Jimenez M. Experimental transmission of Trypanosoma cruzi by Ornithonyssus bacoti. Veterinaria Mexico, 1994, 25, 61-63.

Cortinas M.R., Guerra M.A., Jones C.J. \& Kitron U. Detection, characterization, and prediction of tick-borne disease foci. International Journal of Medical Microbiology, 2002, 291, 11-20.

Coulter J.B.S. Global importance of parasitic disease. Current paediatrics, 2002, 12, 523-533.

Diagne M., Petit G., Seureau C \& Bain C. Development of the filaria Litomosoides galizai in the acarian vector. Annales de Parasitologie Humaine et Comparée, 1989, 64, 478-488.

Dong B. Experimental studies on the transmission of haemorrhagic fever with renal syndrome virus by gamasidea mites and fleas. Chinese Medical Journal, 1991, 71, 502504.

Durden L.A. \& Turell M.J. Inneficient mechanical transmission of Langat (tick-borne encephalitis virus complex) virus by blood-feeding mites (Acari) to laboratory mice. Journal of Medical Entomology, 1993, 30, 639-641.

Durden L.A., LinTHicum K.J. \& MONATH P. Laboratory transmission of eastern equine encephalomyelitis virus to chickens by chicken mites (Acari: Dermanyssidae). Journal of Medical Entomology, 1993, 30, 281-285.

Durden L.A., LinThicum K.J. \& Turell M.J. Mechanical transmission of Venezuelan equine encephalomyelitis by hematophagous mites (Acari). Journal of Medical Entomology, 1992, 9, 118-121.

ELDRIDGE B.F. The epidemiology of arthrobornes diseases. In: Medical Entomology, Eldbridge B.F. \& Edmans J.D. (eds), Kluwer Academia Publisher, Netherlands, 2000, 165-185.

FRANK C. The importance of Laelaps agilis C.L. Kock 1836 (Mesostigmata; Parasitiformae) as a vector of Hepatozoon sylvatici Coles 1914 (Sporozoa; Haemogregarinidae). Zeitschrift für Parasitenkunde, 1977, 53, 307-310.

Gil'Manova G.Kh., BoIKo V.A. \& Lapshina G.N. Participation of gamasoid mites in the circulation of tick-borne encephalitis virus in natural foci of the Tatar ASSR. Medskaya Parazitology, 1964, 33, 157-161.
Grebenyuk R.V., Chirov P.A. \& Kadysheva A.M. The role of wild animals and blood-sucking arthropods in the epizootiology of infection with Listeria. Rol' Dikikh Zhivotnykh i Krovososushchikh Chlenistonogikh v Epizootologii Listerioza, 1972.

GUBLER D.J. The global emergence/resurgence of arboviral diseases as public headline problems. Archives of Medical Research, 2002 a, 33, 330-342.

GuBlER D.J. Epidemic dengue / dengue hemorrhagic fever as a public headline, social and economic problem in the $21^{\text {st }}$ century. Trends Microbiology, 2002 b, 10, 100-103.

Guiguen C. \& Degeilh B. Les tiques d'intérêt médical : rôle vecteur et diagnose de laboratoire. Revue Française des Laboratoires, 2001, 338, 49-57.

Huebner R.J., Jellison W.L. \& Pomerantz C. Rickettsialpox, newly recognized rickettsial disease. IV. Isolation of a rickettsia apparently identical with the causative agent of Rickettsialpox from Allodermanyssus sanguineus, a rodent mite. Public Health Reports, 1946, 61, 1677-1682.

Iakimenko V.V., Bogdanov I.I., Tagil'Tsev A.A., Drokin D.A. \& Kalmin O.B. The characteristics of the relationships of arthropods of the refuge complex with the causative agents of transmissible viral infections in bird rookeries. Parazitologiia, 1991, 25, 156-162.

Iakimenko V.V., Dekonenko A.E., Mal'Kova M.G., KuZ’min I.V., Tantsev A.K., Dzagurova T.K. \& Tkachenko E.A. The spread of hantiviruses in western Siberia. Medicinskâa parazitologiâ i parazitarnye bolezni, 2000, 3, 21-28.

Kocianova E. Nest ectoparasites (gamasid mites) as vectors for rickettsia under experimental conditions. Trudy Instituta Imeni Pastera, 1989, 66, 89-94.

Kocianova E. \& KozUcK O. A contribution to the parasite fauna in winter nests of the common mole (Talpa europaea L.) and incidence of its indection with tick-borne encephaliti virus (TBE) and rickettsia Coxiella burnetii. Folia Parasitologica, 1988, 35, 175-180.

Kocianova E., Kozuch O., Bakoss P., Rehacek J. \& Kovacova E. The prevalence of small terrestrial mammals infected with tick-borne encephalitis virus and leptospirae in the foothills of the southern Bavarian forest, Germany. Applied Parasitology, 1993, 34, 283-290.

Korenberg E.I., Pchelkina A.A. \& Kovalevsky J.V. Contact of birds with tick-borne encephalitis virus in the eastern part of the russian plain. Journal of Hygiene, Epidemiology, Microbiology and Immunology, 1993, 28, 65-72.

Kornilova G.V., Raikhlin M.I., Iastrebov V.K., Shaiman M.S. \& Egorova L.S. New findings concerning the spread of natural foci of infection in the transpolar region of eastern Siberia. Zurnal mikrobiologii, èpidemiologii i immunobiologii, 1975, 11, 96-100.

Lopatina Iu.V., Vasil'eva I.S., Gutova V.P., Ershova A.S., Burakova O.V., Naumov R.L. \& Petrova A.D. An experimental study of the capacity of the rat mite Ornithonyssus bacoti (Hirst, 1913) to ingest, maintain and transmit borrelia. Medicinskaâ parazitologiâ i parazitarnye bolezni, 1999, 2, 26-30.

Lysy J., Nosek J., Vyrostekova V \& Kovacik J. Isolation of Francisella tularensis from mites Haemogamasus nidi and 
Laelaps hilaris in western slovakia. Zentralblatt für Bakteriologie, Parasitenkunde, Infektionskrankheiten und Hygiene, 1979, 244, 324-326.

Meng Yang Chun, Zhuge Hong Xyng, Lan Ming Yang \& Zhou Hong Fu. Experimental study on transmission of haemorrhagic fever with renal syndrome virus by mites, Ornithonyssus bacoti. In: Modern acarology, vol. II. Proceeding of the VIII International Congress of Acarology, Ceske Budejovice, Czechoslovakia, 6-11 august, 1990, 35-39.

Mohamed H.A., Molyneux D.H. \& Wallbanks K.R. A coccidian in haemogamasid mites; possible vectors of Elleipsisoma thomsoni Franca, 1912. Annales de Parasitologie Humaine et Comparée, 1987, 62, 107-116.

NAumov R.L. \& GuTOVA V.P. Experimental study of the participation of gamasid mites and fleas in circulating the tickborne encephalitis virus (a review). Parazitologiia, 1984, 5, 7-14.

Petrov D. Study of Dermanyssus gallinae as a carrier of Pasteurella multocida. Veterinarno - Mededitsinski Nauki, 1975, 12, 32-36.

Petrov V.G. On the role of the mite Ornithonyssus bacoti Hirst in the preservation of the causal agent of tularaemia and transmission to white mice. Parazitologiia, 1971, 5, 7-14.

Poyarkov D.V. \& Avchinnikov V.V. The epizootiological importance of gamasid mites found on rodents inhabiting large towns. Doklady Akademii nauk USSR, 1966, 166, 1005-1008.

Radovsky F.J. Evolution of mammalian mesostigmate mites. In: Coevolution of parasitic arthropods and mammals, Kim K.C. (ed), Wiley, New York, USA, 1985, 441-504.

RADOVSKY F.J. The evolution of parasitism and the distribution of some dermanyssoid mites (Mesostigmata) on vertebrate hosts. In: Mites. Ecological and evolutionary analyse of life-history patterns, Houck M.A. (ed), Chapman \& Hall, New York, 1994, 187-217.

Redington B.C. \& Jachowski L.A. Syngamy and sporogony of Hepatozoon griseisciuri Clark, 1958 (Sporozoa; haemogregarinidae), in its natural vector, Haemogamasus reidi Ewing, 1952 (Acari; mesostigmata). The Journal of Parasitology, 1971, 57, 953-960.

Reeves W.C., Hammon W. McD., Doetschman W.H., McClure H.E., \& SATHER G. Studies on mites as vectors of Western equine and St-Louis encephalitis viruses in California. The American Journal of Tropical Medicine and Hygiene, 1955, 4, 90-105.

Rehacek J., Zupancicova M., Kovacova E., Urvolgyi J. \& BreZINA R. Study of rickettsioses in Slovakia. II. Infestation of fleas and mites in mole nests in some localities in Central Slovakia with C. burnetii and Rickettsiae belonging to the spotted fever (SF) group. Journal of Hygiene, Epidemiology, Microbiology and Immunology, 1975, 19, 166167.

RENZ A. \& WENK P. Intracellular development of the cottonrat filaria Litomosoides carinii in the vecteur mite Ornithonyssus bacoti. Transactions of the Royal Society of Tropical Medicine and Hygiene, 1981, 75, 166-167.

Reshetnikov P.T. The mite Dermanyssus gallianae, a vector of fowl spirochaetosis. Veterinariia, 1967, 44, 48.
Romasheva L.F. \& UzDenov U.B. Distribution of bacteria of the group Bacillus thuringiensis in arthropods and wild birds. Entomologicheskie Issledovaniya v Kirgizii, 1979, 13, 86-90.

SHAIMAN M.S. \& TARASEVICH L.N. Isolation of tick-borne encephalitis virus from gamasid mites in the far North (Taissyr peninsula) in bioassays in nature guinea pigs. Trudy Instituta Poliomielita $i$ Virusnykh Entsefalitov, AMN SSSR, 1976, 22, 87-90.

Shirinov F.B., Ibragimova A.I. \& Misirov Z.G. The dissemination of the fowl-pox by the mite Dermanyssus gallinae. Veterinarya, 1972, 4, 48-49.

Sonenshine D.E., Bozeman F.M., Williams M.S., Masiello S.A., Chadwick D.P., Stocks N.I., Lauer D.M. \& Elisberg B.L. Epizootiology of epidemic typhus (Rickettsia prowazekii) in flying squirrels. The American Journal of Tropical Medicine and Hygiene, 1978, 27, 339-349.

Sotnikova A.N., Sheremet'eva O.F. \& Soldatov G.M. The discovery of a pseudotuberculosis epizootic among housemartins in north-western Mongolia. Primorskaya Protivochumnaya Stantsiya, USSR, 1977, 102-103.

Stajkovic N., Obradovic M., Lako B., Drndarevic D., DmitroVIC R., Djerkovic V. \& Djordjevic D. The first isolation of Borrelia burgdorferi in Apodemus flavicollis in Yugoslavia. Glas Srpska Akademija Nauka I Umetnosti Odeljenje Medicinskib Nauka, 1993, 43, 99-105.

STURMAN I.I. The role of chicken mites in pasteurellosis infection. Veterinariia, 1965, 42, 85-87.

Sulkin S.E., Wisseman C.L., Izumi E.M. \& Zarafonetis C. Mites as possible vectors or reservoirs of equine encephalomyelitis in Texas. The American Journal of Tropical Medicine and Hygiene, 1955, 4, 119-135.

TimofeEva G.Y. Experimental study of the transmission and harbouring of the tularaemia agent by the mite Hirstonysus musculi Johnst. Medskaya Parazitology, 1964, 33, 184-187.

WEGNER Z. Laboratory study on some parasitic hematophagous arthropods as possible subsidiary links of the biocenosis of tick-borne encephalitis. Bulletin of the Institute of Maritime and Tropical Medicine in Gdynia, 1976, 27, 75-85.

Wilson J.E. \& MacDonald J.W. Salmonella infection in wild birds. British Veterinary Journal, 1967, 123, 212-219.

Wu J., Meng Y., Li Y., Zhou H., Zhuge H., Lai P. \& Wang J. Detection of HFRSV in Eulaelaps shanghaiensis and Ornithonyssus bacoti by using in situ hybridization. Chinese Journal of Parasitology and Parasitic diseases, 1998, 16, 441- 444.

Yunker C.E., Brennan J.M., Hughes L.E., Philip C.B., Clifford C.M., Peralta P.H. \& Vogel J. Isolation of viral and rickettsial agents from Panamanian Acarina. Journal of Medical Entomology, 1975, 12, 250-255.

Zeman P., Stika V., Skalka B., Bartik Dusbabek F. \& LavicKova M. Potential role of Dermanyssus gallinae (De Geer, 1778) in the circulation of the agent of pullurosis-typhus in hens. Folia Parasitologica, 1982, 29, 371-374.

Zemskaya A.A \& PChelkina A.A. The relation of gamasid mites to the virus of tick-borne encephalitis. Medskaya Parazitology, 1962, 31, 439-442. 
Zemskaya A.A. \& Pchelnika A.A. Gamasoid mites and Q fever. In: Problemy Parazitologii, Markevich (ed.), Kiev, 1967, 258-259.

Zemskaya A.A. \& PChelnika A.A. On the infection of various species of Gamasidae mites with Rickettsia burnetii in natural foci of Q fever. Zhurnal Mikrobiologii Epidemiologii i Immunobiologii, 1968, 45, 130-132.

Zemskaya A.A. \& PChelnika A.A. The question of the role of gamasid mites in foci of tick-borne encephalitis. Medicinskaâ parazitologiâ i parazitarnye bolezni, 1974a, 43, 405-407.

Zemskaya A.A. \& PCHELNiKa A.A. On the transovarial and transphasic transmission of the virus of tick-borne encephalitis by gamasid mites. Zhurnal mikrobiologii epidemiologii $i$ immunobiologii, 1974b, 8, 130-131.

Zhang Y., Zhu J., \& Deng X. Experimental study on the roles of gamasid mite and chigger mite in the transmission of hemorrhagic fever with renal syndrome virus. Chinese Journal of Epidemiology, 2001, 22, 352-354.

Zhang Y., Zhu J., Deng X., Wu G., Zhang J. \& Zhou Y. Distribution of hemorrhagic fever with renal syndrome virus in gamasid mites and chigger mites. Chinese journal of Preventive Medecine, 2002, 36, 232-234.

Zhuge H., Meng Y., Wu Zhu Z., Liang W. \& Yao P. Studies on the experimental transmission of Rattus-borne Hantavirus by Ornithonyssus bacoti. Chinese Journal of Parasitology and Parasitic diseases, 1998, 16, 445-448.

ZuEvskil A.P. Role of gamasids in the epizootiology of tularaemia. Parazitologiia, 1976, 10, 531-535.

Reçu le 20 novembre 2004 Accepté le 9 février 2005 